Published in Journal of the Philosophy of History 11 (2017), 229-245. Copyright: Brill. PDF of published version: booksandjournals.brillonline.com/content/journals/10.1163/1872263612341322

\title{
What Defines a Professional Historian? A Historicizing Model
}

Herman Paul, Leiden University, Institute for History, h.j.paul@hum.leidenuniv.nl

Review of Rolf Torstendahl, The Rise and Propagation of Historical Professionalism (New York; London: Routledge, 2015), 258 pp., ISBN 978-1-138-80015-1.

\section{Introduction}

Why have scholars of nineteenth-century historiography long tended to approach their subject-matter through the prism of "professionalization"? Part of the attractiveness of this interpretative lens is, no doubt, its potential to examine nineteenth-century historians and their emerging "discipline" as a case study among others. If "professionalization" refers to a set of interrelated processes through which all professions, in and outside the academy, gradually mature, a study of professionalization among nineteenth-century historians allows for comparison across disciplinary boundaries. Also, it allows historians of historiography to draw on a rich body of professionalization theory, such as developed by Harold Wilensky and other organizational sociologists in the third quarter of the twentieth century. ${ }^{1}$ Arguably, however, this is only a partial explanation. At least as important it that "professionalization" is frequently used as synonymous or closely related to "scientification" (Verwissenschaftlichung), an actor's category that featured prominently in the self-images of nineteenth-century historians. If such scholars as Georg Waitz in Germany, Gabriel Monod in France, and Lord Acton in England shared anything, it was a commitment to raising historical studies to the ranks of "science" (Wissenschaft) by setting high scholarly standards, by socializing students into an ethos of painstaking research, and by creating infrastructures for archival research and research dissemination. Given that most historians of nineteenthcentury historical studies are, consciously or not, heirs to this tradition, it does not come as a surprise that many of them find it difficult not to reproduce such actor's categories as "scientification" in their analysis of nineteenth-century historiography. ${ }^{2}$

Like all master narratives, however, "professionalization" turns out to be a problematic template as soon as scholars begin to zoom in and ask what exactly was involved in becoming a professional historian. Some nineteenth-century authors claimed that membership of the historical discipline amounted to using such "historical methods" as codified in Ernst Bernheim's Lehrbuch der historischen Methode (1889) and Charles-Victor Langlois's and Charles Seignobos's Introduction aux études historiques (1898). Does this imply, however, that those rejecting the concept of methods and/or the type of philological source criticism advocated under its banner did not count as "professionals"? Or does it suggest that different ideals of professionalization existed alongside each other, in the sense that historians committed to identifying patterns of cultural change (Karl Lamprecht) and historians advocating a rapprochement between historical inquiry and political science

\footnotetext{
${ }^{1}$ See, e.g., Harold L. Wilensky's highly influential “The Professionalization of Everyone?”, The American Journal of Sociology, 70 (1964), 137-158.

2 Judging by such recent publications as the Atlas of European Historiography: The Making of a Profession 18002005, ed. Ilaria Porciani and Lutz Raphael (Basingstoke: Palgrave Macmillan, 2010).
} 
(Herbert Baxter Adams) held different ideals of what it meant to be a professional historian than those committed to methodological purity? But if that is the case, how meaningful then is the claim that nineteenth-century historiography underwent a process of professionalization?

The examples just given come from The Rise and Propagation of Historical Professionalism by Rolf Torstendahl, emeritus professor of history at Uppsala University. The aim of this book, which largely consists of previously published book chapters and journal articles, is to challenge teleological narratives of professionalization by emphasizing the context-dependency of professional norms and standards. Focusing on late nineteenth and twentieth-century European historiography, with examples from Germany, France, Russia, and the Nordic countries in particular, Torstendahl examines different conceptions of "professionalism", which sometimes greatly differed from each other, but frequently also overlapped, because of a shared commitment to historical methods. The Rise and Propagation is primarily a historical study, devoted to answering historical questions about the development of historical scholarship, although it contains a few philosophical asides, addresses a few long-standing philosophical problems, is not afraid of borrowing philosophical concepts, and presents a model for analyzing "professionalism" that has more normative ambitions than is customary in the genre.

In this review essay, I shall not comment on each of Torstendahl's quite varied chapters. I will keep silent about his comparison between Leopold von Ranke and Douglass C. North (Chapter 4), touch only in passing on the International Historical Congresses that are the subject of Chapter 7, and ignore Torstendahl's comments on global history and microstorie (Chapters 8 and 9). What I will do instead is (1) summarize Torstendahl's model for analyzing "professionalism," (2) explicate the narrative behind this model, (3) raise a few questions, with regard to both the narrative and the model, and (4) offer some brief suggestions as to how to continue Torstendahl's research program. And I do all this, despite some divergence of views, in a spirit of appreciation of the work of a scholar who has enriched the field with a number of landmark articles, including especially his well-known and often-cited "Fact, Truth, and Text: The Quest for a Firm Basis of Historical Knowledge around 1900" (included in this book as Chapter 6).

\section{Torstendahl's model}

Professionalization, to start with, has often been treated as a category of historical analysis that should be defined as unambiguously as possible. Pim den Boer, for example, takes it to refer to an increase in the number of "professionals," with the latter term including all "those who earn their living from the study of history." ${ }^{3}$ In a more qualitative mode, Gabriele Lingelbach equates professionalism with the existence of a recognized educational system paired to well-established procedures for examination and peer-review. Although such quality assessment systems cannot be identified as straightforwardly as salary payments, Lingelbach agrees with den Boer that professionalism as a category of analysis should be as clear and unequivocal as possible. ${ }^{4}$

In marked contrast to these two scholars, Torstendahl treats professionalization as a subjective category. For him, professional historians are those who are accepted as such by

\footnotetext{
${ }^{3}$ Pim den Boer, History as a Profession: The Study of History in France, 1818-1914, trans. Arnold J. Pomerans (Princeton: Princeton University Press, 1988), pp. xiv, xv.

${ }^{4}$ Gabriele Lingelbach, Klio macht Karriere: die Institutionalisierung der Geschichtswissenschaft in Frankreich und den USA in der zweiten Hälfte des 19. Jahrhunderts (Göttingen: Vandenhoeck \& Ruprecht, 2003), pp. 26-27.
} 
the scholarly community in their own time and place. Torstendahl's definition of professionalization is, therefore, subjective in the sense that is actor-based. What it includes and excludes varies from case to case, given that it depends on what communities of historians in different times and places recognize as "professional." This has an advantage, too. Instead of superimposing a timeless standard on a historical discipline that evolves over time, it acknowledges that professional norms are produced in social contexts and therefore likely to change in tandem with them. It seeks to avoid an essentialist conception of "the" historical discipline as well as a reified notion of professional conduct by highlighting that professional norms are expressions of culturally sanctioned ideals and therefore never etched in stone. They change when historians embrace new ideals or when societies impose different demands on students of the past. In Torstendahl's own words: "[P]rofessionalism is an understanding within the community of historians, which means that a community is a precondition and that the community may change the conditions for professionalism" ( $p$. 12). ${ }^{5}$

Interestingly, this claim can also be reversed, given that Torstendahl defines a community in terms of professional norms: "This community is not an organization but consists of those who have an established position in scholarship, respected as 'good historians' by others" (p. 13). So it seems that, for Torstendahl, scholarly communities and the norms to which they are committed are dialectically dependent on each other. Scholarly communities change when their normative systems change, just as professional norms change if there is communal support for it. "Thus, if the community of historians wants to decide that aesthetic norms should play certain crucial roles in the formation of historical knowledge and replace part of the previous normative system, it is up to the community to do so" (p. 21). I take this not as implying that communities have some kind of collective agency, but rather that change in normative systems requires support from a sufficient number of group members. Change is realized not by "one, two, or several theoreticians" ( $p$. 21 ), but by majorities that welcome new standards and/or dissociate themselves from older ones.

Torstendahl then continues by distinguishing between "minimum" and "optimum" norms - which arguably is the most original contribution that The Rise and Propagation makes. Minimum norms are often expressed negatively, in terms of "deficiencies," "violations," or "vices," given that deviation from the norms is often easier to recognize than compliance to them (p. 44). Based on an analysis of what he calls, without further details, "a rather large quantity of reviews and quite a number of scholarly books" (p. 25), Torstendahl argues that such deviation occurs in four forms:

- deficiencies in logical consistency, mainly in the use of concepts, which give rise to contradictions;

- a lacking possibility to check the empirical basis or mistakes in the handling of sources for statements on factual circumstances, leading to a lack of intersubjective empirical reliability;

- a deficient internal coherence insofar as it is not clear in which way one particular argument is relevant for a specific result or in which way a result is relevant for other arguments and results;

\footnotetext{
${ }^{5}$ Page numbers in parentheses refer to the book under review.
} 
- a lack of new results in the sense that everything that is stated as results of the investigation has already been stated by other researchers in investigations beyond doubt (p. 25).

In addition to these minimum norms, which Torstendahl believes to be widely shared among historians, there are optimum norms. They specify not what is "required" from historians, but what is "desirable," "interesting," or "lovely," in Peter Lipton's technical sense of that word (pp. 35, 223). ${ }^{6}$ Perhaps one might add: they specify what constitutes scholarly "excellence," or what academic fashion considers this to be. Obviously, unanimity in such delicate matters is more difficult to reach than agreement on minimum norms, if only because social expectations, economic pressures, political agendas, and aesthetic conventions heavily influence what counts as "desirable." As Torstendahl puts it:

Norms that determine what "good scholarship" is do not relate only to internal decisions in the scholarly setting but have to do with what most people think is important in their lives... . The optimum norms of historical scholarship are, therefore, closely knit together with interests that have a closer relation with the attitudes to life and individual and social morality than with the construction of logical arguments (p. 34).

Consequently, minimum and optimum norms also differ in how quickly and profoundly they change. Whereas the latter come and go with the "interests" and "attitudes" that support them, minimum norms are relatively stable. Torstendahl does, of course, not exclude the possibility of change at the minimum level: he cites the acceptance of oral history as a legitimate branch of research as an example of adaptation of minimum norms (p. 37). He emphasizes, however, that such changes are rare, and must be rare if minimum norms are to fulfill their function of providing unity to an otherwise quite diverse field of historical studies. For only as long as different "paradigms" (gender history, global history, etc.) respect the same set of minimum norms, they can "exist side by side in respected universities, journals, and handbooks" (p. 37).

On which of these levels, then, must "professionalism" be located? Torstendahl's answer is that "professionalism," understood as the value system employed in evaluating historical work (p. 89), sometimes refers to minimum norms, sometimes to optimum norms, and sometimes to a combination of both. That is to say: while some historians define "professionalism" in terms of minimum norms only, other, more demanding colleagues also require historians to conform to certain political agendas and/or aesthetic conventions. Such differences are not without consequences: they have profound implications for how the community of historians looks like. For if membership only requires adherence to minimum norms, the community is likely to be large and diverse as far as optimum norms are concerned. By contrast, communities based on value systems that, from Torstendahl's perspective, treat optimum norms as if they were minimum norms are likely to develop sectlike qualities. By refusing to accept colleagues committed to other optimum norms as "professionals," they tend to cause schism within the historical discipline at large. Clearly, then, some "professionalisms" are more ecumenical than others, and more beneficial to the unity of the historical discipline.

\footnotetext{
${ }^{6}$ Peter Lipton, Inference to the Best Explanation, 2nd ed. (London; New York: Routledge, 2004), pp. 59-60.
} 
This argument has a philosophical as well as an historical side to it. Philosophically speaking, Torstendahl's distinction between minimum and optimum norms is an attempt at steering a middle course between "universalism" and "relativism." On the one hand, the distinction allows Torstendahl to recognize that different groups of historians have defined the relative importance of minimum and optimum norms in different ways. This is the historicizing or "relativizing" element in Torstendahl's analysis, which directly follows from his decision to treat "professionalism" as an actor's category. Striking, however, is that this historicization, on the other hand, does not extend itself to the categories of minimum and optimum norms. For although Torstendahl acknowledges that the content of these categories can change - slow in the case of minimum norms, quicker in the case of optimum ones - the classification as such is not subjected to historical analysis. It is Torstendahl who labels the norms in the bulleted list above as minimum ones, just as it is Torstendahl who classifies everything resembling politics, religion, and aesthetics as "desirable" or "lovely" instead of "required." This normative stance, then, allows Torstendahl to claim that he acknowledges historical variety while at the same time rejecting the "anything goes" often associated with historicizing agendas. In his own words: "[M]y standpoint is constructivist in a general sense but rejects postmodernism's total relativism" (p. 2).

How plausible this is from an historical point of view depends, of course, on the extent to which Torstendahl's minimum norms actually served as baseline criteria for membership of the historical discipline. Torstendahl's answer is that, empirically speaking, historians have been subscribing to his minimum norms for more than a century. Ever since the emergence of a "methodological consensus" in late nineteenth-century Europe, logical consistency, empirical reliability, internal coherence, and originality are standards that virtually all historians expect each other to adhere to. This consensus is still in place, even though the twentieth century has witnessed several historiographical reform movements that threatened the unity of the discipline by conflating optimum and minimum norms. Torstendahl's model therefore presupposes an historical narrative: a story about "how the profession of historians was established and how the community has repeatedly tended to break up into several without really doing so" (p. 16).

\section{Torstendahl's narrative}

The story is a drama in three and a half acts. In illo tempore, there was no historical discipline. Until the early nineteenth century, writes Torstendahl under reference to Peter Burke and Edoardo Tortarolo, historians worked in relative isolation, without shared value systems, without recognizable "schools" committed to a particular type of doing history. "It is not contended here that communities did not exist at all until the nineteenth century, but is seems quite clear that the communities among historians before this century were local and embryonic" (p. 45). This changed, however, with Leopold von Ranke, who exercised such a considerable influence, mostly through his many students, that for the first time in history something like a shared value system among historians began to emerge. By the midnineteenth century, it was "not possible to adhere to the community of historians" without subscribing to Rankean standards (p. 48). In line with recent Ranke scholarship, ${ }^{7}$ Torstendahl emphasizes that these were no methodological standards stricto sensu, even though the use of primary sources was closely associated with Ranke's name. More important for Ranke was the practicing of a political history focused on the rise and development of nation states. "It

\footnotetext{
${ }^{7}$ E.g., Günter Johannes Henz, Leopold von Ranke in Geschichtsdenken und Forschung, vol. 1 (Berlin: Duncker \& Humblot, 2014).
} 
was necessary not only to write a faultless account but above all of look at the historical development from the notions of state and politics that Ranke had formulated" (p. 48). In terms of Torstendahl's model, this amounts to saying that Ranke turned optimum norms into requirements, which in turn implies that a large and stable community of historians was difficult to imagine on a Rankean basis. For no matter how influential Ranke as a teacher was, the premises of his professionalism were too German and too much indebted to idealist philosophy to serve as principles for an entire profession.

A global professional community only emerged in the second act, marked by the appearance of such often reprinted methodology manuals as the aforementioned Lehrbuch der historischen Methode by Ernst Bernheim and the Introduction aux études historiques by Charles-Victor Langlois and Charles Seignobos. For Torstendahl, these manuals represented a "second appearance of historical professionalism" (p. 53) to the extent that they identified professionalism with adherence to basic methodological standards. Across the world, historians who so far had been working individually or in small, nationally oriented communities, recognized the attractiveness of this model. For Torstendahl, the entire infrastructure of journals, professional associations, conferences, and book series that was created in the decades around 1900 testifies to the spread of this "methodological consensus." For it was on the basis of methodological minimum norms that historians of different nationalities, political leanings, religious affiliations, and fields of specialization could accept each other as colleagues without having to share optimum norms. In Torstendahl's optimistic assessment: "The microcosms of historical communities had all fundamentals in common thanks to the widespread manuals. A wider consensus grew up, and the international community was extended and cemented" (p. 50).

Much of this remained in place during the third act, despite the fact that this phase, from the mid-twentieth century to the 1980s, was characterized by the rise of various forms of social and economic history. Under reference to such familiar names as Marc Bloch, Fernand Braudel, and Eric Hobsbawm, Torstendahl argues that "social science history" focused mainly on optimum norms. It replaced the state as a central category of analysis by "the people" and preferred left-wing politics over the conservatism associated with nineteenth-century historicism. This, however, left most of the existing methodological minimum norms intact: no one advocated abandonment of source criticism. Apart from that, "narrative-hermeneutic political history" (p. 62), as Torstendahl calls it, never entirely disappeared. The historiographical schools of the Annales, Geschichte und Gesellschaft, and the History Workshop Journal were therefore not as revolutionary as they might have considered themselves. Although they represented new forms of professionalism, each with their own characteristic mix of minimum and optimum norms, the general methodological consensus was still in place (p. 62).

But how long will this be the case? The drama becomes exhilarating in the fourth phase, which I call the third-and-a-halfth, because the act is still underway and its outcome unsure. Characteristic of this phase, in which Torstendahl locates himself and his readers, is the rise of "postmodernism," which the author sees as threatening the very foundations of the historical discipline. "Some scholars," writes Torstendahl,

propose quite modified minimum demands compared to those of an earlier generation, and they are sometimes getting support from leading theoreticians and journals. If this description is correct, as I think it is, the community of professional 
historians is in danger of being split into different communities with different minimum demands (p. 38).

Who these villains are remains implicit, but that they have the capacity of destroying the historical community by questioning its minimum norms seems beyond doubt. Torstendahl's analysis here reads like Peter Novick's "there was no king in Israel": a rather pessimistic assessment of the present situation in terms of "individualism" and "relativism." ${ }^{8}$ "Formally," says Torstendahl, "the discipline is still there, but the differences between its practitioners and their different communities are great" (p. 64). So, as long as historians do not protest and join forces against the destructive powers of "postmodernism," the drama in which they participate may well become a classic tragedy, or an ironic one perhaps, in Hayden White's sense of the word, given that historians will then be back at where they started, before the nineteenth century, in a world without coherent value systems, without shared minimum norms, and without a community at large to belong to.

Striking about this narrative is that it simultaneously resembles and dissociates itself from classic accounts of "professionalization" as a single, teleological process. On the one hand, it rejects this master narrative because "professionalism" is an actor's category, because actors disagree on what it takes to be a professional, and because, consequently, different actors will tell different stories about the extent to which their ideals of professionalism have been realized. On the other hand, just like the older professionalization story, Torstendahl's narrative as summarized in the previous paragraphs is a simple, monolinear story with late nineteenth-century "scientific" historians as heroic protagonists. It is also a narrative in which Northern German, Protestant historians play a decisive role Torstendahl's French and Russian examples notwithstanding. It is a story that values unification over fragmentation and prioritizes "methods and methodology" (p. 62) over the political, religious, and aesthetic dimensions of historical scholarship. So, despite the author's rejection of Whiggish teleologies, the "scientific" aspirations of late nineteenthcentury German historiography remain a point of identification. Both Torstendahl's model and his narrative are indebted to late nineteenth-century metaphors of "kernel" (historical methods) and "shell" (all the rest).

\section{Some questions}

Any attempt at evaluating The Rise and Propagation must therefore start with the question: how convincing is the claim that historical methods of the kind propagated in Bernheim's Lehrbuch served as membership criteria for a worldwide community of historians? As far as I can see, Torstendahl offers six arguments in support of this thesis:

- late nineteenth-century methodology manuals resembled each other: they conveyed similar sets of minimum demands (p. 23);

- these manuals were widely read, judging by reprints, translations, and imitations of, most notably, Bernheim's book (p. 23);

- historical seminars helped socialize new generations of historians in historical methods (pp. 88-89);

- national historical associations were divided over "philosophical and political issues," but found "a common basis" in historical methods (p. 103);

\footnotetext{
${ }^{8}$ Peter Novick, That Noble Dream: The "Objectivity Question" and the American Historical Profession (Cambridge: Cambridge University Press, 1988), pp. 573-629.
} 
- historical journals published book reviews that "spurred methodological interest" (p. 103);

- international conferences such as those organized by what would later become the Comité International des Sciences Historiques devoted ample attention to methodological issues (p. 103).

These are all pertinent observations, which illustrate the importance of "historical methods" in European historiography around 1900. One would wish that Torstendahl or someone else would write a cultural history of "historical methods," showing in more concrete detail what it was that made scholars feel attracted to this language of "methods." But as long as such a history has not been written, I am not sure whether the six points above provide sufficient evidence for Torstendahl's claim that adherence to clearly defined research methods served as a membership requirement for the historical discipline.

First of all: although the six points illustrate that methods were a prominent issue of debate, how do they prove that all historians actually agreed on what these methods were, on how important they were, and on how they should be used? It is true, as Torstendahl says, that most late nineteenth- and early twentieth-century manuals discussed a more or less similar set of research techniques by means of which historians could subject their source material to "internal" and "external" criticism. But this, of course, was not what made methods interesting or important. Decisive, I would say, was rather the kind of attitude advocated under the banner of "source criticism" or "historical methods." This was an attitude of suspicion vis-à-vis traditional authorities, skepticism as a default strategy in matters of interpretation, and commitment to independent, if possible "impartial" scholarly judgment. What explains the proliferation of methodology manuals in the decades around 1900 is not, I think, agreement on research techniques, but disagreement on the merits and limitations of this "critical" attitude. The many Catholic historians contributing to the genre are a case in point. If they had only been interested in conveying minimum demands, they could easily have assigned Bernheim or Langlois and Seignobos to their students. Instead, these Catholic historians (church historians included) often wrote their own methodology manuals, which typically relied on Bernheim's in so far as "internal" and "external" source criticism were concerned, but added chapters on such sensitive questions as to what extent the papacy or the lives of the saints could be subjected to critical scrutiny or how the muchlauded virtue of "impartiality" could be reconciled with traditional religious values. ${ }^{9}$

Secondly, even if the rhetoric of "historical methods" figured prominently in the selfdescriptions of historians eager to be seen as "scientific," "modern," and "up to date," how does it follow from this that adherence to such methods actually served as a membership requirement for the historical discipline? Torstendahl offers no examples demonstrating that historians who performed badly in this regard were excluded as community members. Not that such examples are impossible to find: Mario Krammer's early retirement from the Monumenta Germaniae Historica in 1924 was a direct consequence of the widely publicized protest elicited by his unprofessional edition of the Lex Salica ("his method is arbitrary"). ${ }^{10}$ In

\footnotetext{
${ }^{9}$ Bernhard Steinhauf, Die Wahrheit der Geschichte: zum Status katholischer Kirchengeschichtsschreibung am Vorabend des Modernismus (Frankfurt am Main: Peter Lang, 1999), pp. 268-304.

${ }^{10}$ Ines Oberling, Ernst Perels (1882-1945): Lehrer und Forscher an der Berliner Universität (Bielefeld: Verlag für Regionalgeschichte, 2005), p. 100. The quotation comes from G. v[on] Below, "Gutachtliche Aeusserung über Krammers Ausgabe der Lex Salica," Neues Archiv der Gesellschaft für Ältere Deutsche Geschichtskunde, 41 (1919), 405.
} 
less spectacular cases, however, fierce methodological criticism did not necessarily block a future career in the historical profession. In 1906, for example, the Berlin historian Eduard Meyer judged that Francis Smith's dissertation, Die römische Timokratie, employed a "method that stands in such vehement opposition to everything I consider and teach as scientific [wissenschaftlich]" that he asked for faculty deliberation - only to find out that his colleagues were happy to tolerate the "entirely unscientific [unwissenschaftliche] method" of Smith and his supervisor, Hans Delbrück. ${ }^{11}$ Smith therefore obtained his doctorate and could continue his career with a second promotion (Habilitation) at the University of Leipzig and a publication in Germany's most prestigious historical journal. ${ }^{12}$

If such examples offer one reason why a one-to-one relation between violation of "historical methods" and professional excommunication does not seem to have existed, another one is that inclusion and exclusion often depended on social factors as much as on professional performance. One reason why, in Imperial Germany at least, Jewish historians were sensitive to issues of historical method was that they represented "subaltern" voices often suppressed in the hegemonic discourse of Prussian Protestants. ${ }^{13}$ Think only of Harry Bresslau, a Jewish student of Ranke, who was advised by his teacher to convert to Protestantism if he aspired to an academic career. When Bresslau, this anti-Semitism notwithstanding, acquired some power in the discipline, he in turn excluded Heinrich Graetz, a more apologetic Jew than Bresslau himself, from the Historical Commission for the History of the Jews in Germany, on the ground that outspoken figures like Graetz fueled antiSemitism in the historical profession. ${ }^{14}$ Even Bernheim, a liberal and thoroughly "assimilated" Jew, experienced in the 1870s that Habilitation in Erlangen was out of reach for him (in 1886 he would convert to Protestantism). ${ }^{15}$ Similar stories can be told about Catholic historians and, of course, about female historians. ${ }^{16}$ Given such social exclusion mechanisms, isn't it a bit of an oversimplification to assume that methodological virtuosity was all that counted?

Was there, moreover, a single historical profession - "the" historical discipline - to which historians could belong or it is more accurate to speak about a network of partly overlapping, partly also distinct historical communities that were organized, primarily, along geographical and religious lines? If we stay with the example of late nineteenth-century Germany, historical research was not only conducted at universities, but also in dozens of local and regional historical associations and on behalf of historical commissions (in Bavaria, Hessen, and Westphalia, for example). Catholic historians, moreover, had organized themselves in the Görres Society (1876), which ran a journal of its own as well as an institute in Rome. Although little research has been done on the relation between these institutions,

\footnotetext{
${ }^{11}$ Eduard Meyer to Georg Wissowa, 11 November 1906, in Gelehrtenalltag: der Briefwechsel zwischen Eduard Meyer und Georg Wissowa (1890-1927), ed. Gert Audring (Hildesheim: Weidmann, 2000), pp. 236, 237.

${ }^{12}$ Francis Smith, “Die Schlacht bei Carrhä," Historische Zeitschrift, 115 (1916), 237-263.

${ }^{13}$ This phrasing is indebted to Roberto M. Dainotto, Europe (in Theory) (Durham, NC: Duke University Press, 2007), who treats historicism as “the ideology and methodology of a subaltern Europe - Vico's Italy, Herder's Germany, and Andrés's Spain - pitted against the unbearable hegemony of France" (p. 118)

${ }^{14}$ Aleksandra Pawliczek, "Zwischen Anerkennung und Ressentiment: der jüdische Mediävist Harry Bresslau (1848-1926)," Simon Dubnow Institute Yearbook, 6 (2007), 389-409; Nils Roemer, Jewish Scholarship and Culture in Nineteenth-Century Germany: Between History and Faith (Madison, WI: University of Wisconsin Press, 2005), pp. 95-96.

${ }^{15}$ Mircea Ogrin, Ernst Bernheim (1850-1942): Historiker und Wissenschaftspolitiker im Kaiserreich und in der Weimarer Republik (Stuttgart: Franz Steiner, 2012), pp. 26, 42.

${ }^{16}$ Bonnie G. Smith, The Gender of History: Men, Women, and Historical Practice (Cambridge, MA: Harvard University Press, 1998).
} 
it seems not unlikely that membership requirements of the Görres Society differed from those of the Aachen Historical Society and that the question "Who counts as a historian?" was answered differently in the Historical Commission at the Bavarian Academy of Sciences than by the editor of the Hansische Geschichtsblätter. Doesn't it take some wishful thinking, then, to assume that all these institutions agreed on minimum norms? There is, of course, a risk of overemphasizing variety at the cost of what Torstendahl calls "centripetal force[s]" in late nineteenth-century historical scholarship (p. 5). No less real, however, is the opposite danger. It is worth remembering, therefore, that in spite of the growing importance of "historical methods," disagreement over what made a professional historian was ubiquitous, even in the heartland of historical methods that was Imperial Germany.

I draw attention to this diversity among late nineteenth-century historians, not merely because the decades around 1900 serve as a "golden age" in Torstendahl's story, but also because his narrative invokes the "unity" of nineteenth-century historical studies as a contrast image to the "fragmentation" characteristic of, especially, the closing decades of the twentieth century. If it can be shown that the nineteenth-century "unity" was less robust and more contested than Torstendahl assumes, then the diversity experienced by later generations of historians may, in effect, also turn out to be less dramatic, less spectacular, and less disturbing.

\section{One more question}

Torstendahl's distinction between minimum and optimum norms also raises a question, especially in so far as it assumes that minimum requirements are methods of the sort codified by Bernheim, Langlois, and Seignobos. For what is characteristic about the methods expounded in these late nineteenth-century manuals is that quite a few them are, strictly speaking, not "rules" that can be followed unambiguously, but "virtues" that people possess and practice only to a certain degree. Since I have made this argument elsewhere for Bernheim's Lehrbuch, ${ }^{17}$ let me here use Seignobos and Langlois as an example. Whenever these French historians describe what sort of demands the scientific study of the past makes on the historian, they use virtue language. Take the following passage:

It is rightly said that patience is the cardinal virtue of the scholar. ... The true scholar is cool, reserved, circumspect. In the midst of the turmoil of life, which flows past him like a torrent, he never hurries. Why should he hurry? The important thing is, that the work he does should be solid, definitive, imperishable. ... Whatever special branch of critical scholarship a man may choose, he ought to be gifted with prudence, an exceptionally powerful attention and will, and, moreover, to combine a speculative turn of mind with complete disinterestedness and little taste for action ... ${ }^{18}$

This passage does not describe research techniques or skills that can be taught in a research seminar. Langlois and Seignobos rather speak about virtues or character traits that prospective scholars must possess well before they enter university. If they do not have a "puzzle-solving instinct," combined with "an exceptional appetite for work" and "the qualities of order, industry, and perseverance," they better embark on a different career. For

\footnotetext{
${ }^{17}$ Herman Paul, “Distance and Self-Distanciation: Intellectual Virtue and Historical Method around 1900," History and Theory, Special Issue 50 (2011), 104-116.

${ }^{18}$ Ch. V. Langlois and Ch. Seignobos, Introduction to the Study of History, trans. G. G. Berry (New York: Henry Holt and Company, 1932), pp. 126, 127.
} 
history, Langlois and Seignobos add, is not a field for men of "average ability" and "moderate intellects." It is, indeed, quite wrong to assume that "a special drilling" in historical methods will make a useful historian out of an mediocre student. Historical scholarship requires "aptitudes" of mind or dispositions that guide and control the scholar's work on the delicate task of source criticism. ${ }^{19}$

Significant, for our purposes, it that this passage uses maximalist instead of minimalist language in defining the marks of the "true scholar." Describing the good historian in terms of virtues amounts to invoking ideals that even the most talented and dedicated scholar can only realize to some degree. This does not imply that Langlois and Seignobos require historians to transcend the realm of what is humanly possible ("complete disinterestedness"), but rather that they set high standards and encourage historians to approach these standards as well as they can. Accordingly, the question is not whether historians are circumspect, disinterested, industrious, and perseverant, but to what extent they practice these virtues. Virtues cannot be ticked off a checklist, but are measured at a gliding scale ("Is this historian sufficiently disinterested?"). And from this it follows that unambiguous minimum requirements cannot easily be formulated. Even if historians agree that the virtues listed in Langlois's and Seignobos's Introduction aux études historiques should guide professional conduct, they may have a hard time figuring out where to draw the distinction between "acceptable" and "unacceptable." Language of virtue and vice does not offer clear cut demarcation criteria.

In such a virtue discourse, moreover, it is quite difficult to relegate political, moral, and religious concerns to the non-committal realm of what is "desirable" or "lovely," as Torstendahl's model seeks to do. For the virtues invoked by Langlois and Seignobos all have moral or political connotations, if only because they reflect bourgeois societal expectations that nineteenth-century academics were supposed to meet. Even if, with a slightly anachronistic twist, circumspection, disinterestedness, and perseverance can be classified as "epistemic virtues," because they are aimed at epistemic goods (knowledge and understanding of the past), this does not change the fact that they are, at the same time, "qualifications of the moral rather than the intellectual order," as Langlois and Seignobos observe. $^{20}$ The adjective "epistemic" should therefore not be interpreted exclusively: in nineteenth-century historical scholarship, distinctions between "knowledge," "politics," and "morality" are relative ones.

\section{Conclusion}

Where does this leave us? Is Torstendahl's commitment to historicizing the notion of "professionalization" inextricably bound up with his somewhat forced distinction between minimum and optimum norms? Or would it be possible to separate the two and approach the question how communities of historians in the past defined the marks of a "professional" scholar from the perspective of the virtue language they used to that end? If we would take our point of departure in virtues of the sort recommended by Bernheim, Langlois, and Seignobos, we would observe, first of all, that virtues often came in clusters for what mattered was not "accuracy" or "synthesizing power," but a right balance between them - and that such constellations, secondly, were typically embodied by larger-than-life examples. When, for instance, the young historian Friedrich von Bezold wondered whether he should turn to "Waitz" or to "Sybel," these names did not primarily refer to individuals,

\footnotetext{
${ }^{19}$ Ibid., pp. 128, 129.

${ }^{20}$ Ibid., p. 124.
} 
but to types of historical scholarship embodied by these two professors. ${ }^{21}$ Much the same is true for Friedrich Christoph Dahlmann and Johannes Janssen, whose names often served as metonymies for the models of the "political professor" and the "Catholic apologist," respectively. Following Lorraine Daston and others, we might call such types "personae," each of which is characterized by a typical constellation of virtues, among other things. ${ }^{22}$

On the one hand, these personae fit badly with Torstendahl's model, because they combine, each in their own way, "minimum" and "optimum norms." On the other, however, they serve Torstendahl's purpose of writing a non-relativistic history of historical scholarship. For although personae come in the plural and change over time, there is not an infinite number of them. If we treat them as ideal-types, there number is limited (depending on the level of generalization). The type of the "political professor," for example, that nineteenthcentury Germans associated with Dahlmann and Sybel made a comeback in more democratic outfit after World War II, just as the "historian-as-essayist," embodied by Alfred Dove in nineteenth-century Germany, was a type reinvigorated by Isaiah Berlin and others in twentieth-century Britain. If we, like Torstendahl, want to trace patterns of change in how historians have defined their profession in the past two centuries, without implying that everything is always open to change, then scholarly personae may serve that goal quite well.

The Rise and Propagation is, in short, a stimulating book that convincingly calls for thorough historicization of "professionalization" as a historiographical master narrative. "Professionalism" is not a timeless ideal, but a contingent set of standards that should be treated as a context-specific response to context-specific questions and concerns - even if the repertoires available for articulating what it takes to be a good historian are limited in number.

\footnotetext{
${ }^{21}$ Walther Hubatsch, “Friedrich von Bezold, 1848-1928," in Bonner Gelehrte: Beiträge zur Geschichte der Wissenschaften in Bonn, vol. 1 (Bonn: H. Vouvier \& Co.; Ludwig Röhrscheid, 1968), pp. 284-292, at p. 285. ${ }^{22}$ Herman Paul, "What Is a Scholarly Persona? Ten Theses on Virtues, Skills, and Desires," History and Theory, 53 (2014), 348-371.
} 